\title{
Chronology of 1920s American
}

\section{Culture}




\begin{tabular}{|c|c|c|c|}
\hline Date & Events & Criticism & Literature \\
\hline 1920 & $\begin{array}{l}\text { Republican Warren } \\
\text { G. Harding elected. } \\
\text { Women granted } \\
\text { national franchise. } \\
\text { Prohibition of } \\
\text { alcohol begins. } \\
4,000 \text { suspected } \\
\text { communists and } \\
\text { radicals arrested, } \\
\text { including Nicolo } \\
\text { Sacco and } \\
\text { Bartolomeo Vanzetti. } \\
\text { Marcus Garvey's } \\
\text { First International } \\
\text { Convention of the } \\
\text { Negro Peoples of the } \\
\text { World. } \\
\text { Deaths of } \\
\text { Hollywood actresses } \\
\text { Olive Thomas and } \\
\text { Virginia Rappe. }\end{array}$ & $\begin{array}{l}\text { George Santayana, } \\
\text { Character and } \\
\text { Opinion in the } \\
\text { United States } \\
\text { Thomas Stearns } \\
\text { Eliot, The Sacred } \\
\text { Wood } \\
\text { Van Wyck Brooks, } \\
\text { The Ordeal of Mark } \\
\text { Twain } \\
\text { Lothrop Stoddard, } \\
\text { The Rising Tide of } \\
\text { Color } \\
\text { Sigmund Freud, } \\
\text { Beyond the Pleasure } \\
\text { Principle } \\
\text { John Dewey, } \\
\text { Reconstruction in } \\
\text { Philosophy } \\
\text { First tabloid } \\
\text { newspaper, New } \\
\text { York Daily News, } \\
\text { published }\end{array}$ & $\begin{array}{l}\text { F. Scott Fitzgerald, } \\
\text { This Side of Paradise } \\
\text { and Flappers and } \\
\text { Philosophers } \\
\text { Ezra Pound, Hugh } \\
\text { Selwyn Mauberley } \\
\text { Edward Bok, The } \\
\text { Americanization of } \\
\text { Edward Bok } \\
\text { Carl Sandburg, } \\
\text { Smoke and Steel } \\
\text { Sinclair Lewis, Main } \\
\text { Street } \\
\text { Edith Wharton, The } \\
\text { Age of Innocence } \\
\text { Zane Grey, The Man } \\
\text { of the Forest }\end{array}$ \\
\hline 1921 & $\begin{array}{l}\text { Emergency } \\
\text { Immigration Act } \\
\text { creates selective } \\
\text { immigration quotas. } \\
\text { Einstein arrives in } \\
\text { New York. } \\
\text { American Birth } \\
\text { Control League } \\
\text { founded. } \\
\text { Lie detector invented. } \\
\text { First Miss America } \\
\text { contest held. }\end{array}$ & $\begin{array}{l}\text { Little magazines The } \\
\text { Double Dealer and } \\
\text { Broom founded } \\
\text { Sigmund Freud, } \\
\text { Group Psychology } \\
\text { and the Analysis of } \\
\text { the Ego } \\
\text { Anne Shaw Faulkner, } \\
\text { 'Does Jazz Put the } \\
\text { Sin in Syncopation?' }\end{array}$ & $\begin{array}{l}\text { John Dos Passos, } \\
\text { Three Soldiers } \\
\text { Sherwood Anderson, } \\
\text { The Triumph of the } \\
\text { Egg } \\
\text { Booth Tarkington, } \\
\text { Alice Adams } \\
\text { Ben Hecht, Erik } \\
\text { Dorn } \\
\text { Dorothy Canfield, } \\
\text { The Brimming Cup }\end{array}$ \\
\hline
\end{tabular}




\begin{tabular}{|c|c|c|c|}
\hline Performance & Film & Music and Radio & Art and Design \\
\hline $\begin{array}{l}\text { Eugene O'Neill, The } \\
\text { Emperor Jones } \\
\text { Zona Gale, Miss Lulu } \\
\text { Bett } \\
\text { Martha Graham } \\
\text { dances in 'Xochitl' }\end{array}$ & $\begin{array}{l}\text { Why Change Your } \\
\text { Wife? (Cecil B. } \\
\text { DeMille) } \\
\text { The Flapper (Alan } \\
\text { Crosland) } \\
\text { Within Our Gates } \\
\text { and The Brute (Oscar } \\
\text { Micheaux) }\end{array}$ & $\begin{array}{l}\text { Mamie Smith records } \\
\text { 'Crazy Blues' } \\
\text { Paul Whiteman } \\
\text { records 'Whispering' } \\
\text { and 'Japanese } \\
\text { Sandman' } \\
\text { George Antheil's } \\
\text { Symphony no. } 1 \\
\text { Radio Corporation } \\
\text { of America (RCA) } \\
\text { founded } \\
\text { First licensed radio } \\
\text { broadcast from } \\
\text { KDKA in Pittsburgh } \\
\text { Presidential election } \\
\text { results announced on } \\
\text { radio }\end{array}$ & $\begin{array}{l}\text { Edward Steichen's } \\
\text { Time/Space } \\
\text { Continuum } \\
\text { Joseph Stella, } \\
\text { The Voice of the } \\
\text { City of New York } \\
\text { Interpreted (1920-22) } \\
\text { Charles Sheeler, } \\
\text { Church Street El }\end{array}$ \\
\hline $\begin{array}{l}\text { Eubie Blake and } \\
\text { Noble Sissle, 'Shuffle } \\
\text { Along' } \\
\text { John Alden } \\
\text { Carpenter, 'Krazy } \\
\text { Kat' } \\
\text { Fletcher Henderson } \\
\text { begins at the } \\
\text { Roseland Ballroom }\end{array}$ & $\begin{array}{l}\text { The Kid (Charles } \\
\text { Chaplin) } \\
\text { The Four Horsemen } \\
\text { of the Apocalypse } \\
\text { (Rex Ingram) } \\
\text { The Affairs of Anatol } \\
\text { (Cecil B. DeMille) } \\
\text { Never Weaken } \\
\text { (Harold Lloyd) } \\
\text { Manhatta (Paul } \\
\text { Strand and Charles } \\
\text { Sheeler) } \\
\text { Clara Bow wins 'The } \\
\text { Fame and Fortune } \\
\text { Contest' }\end{array}$ & $\begin{array}{l}\text { Jack Dempsey beats } \\
\text { Georges Carpentier } \\
\text { in the first boxing } \\
\text { match broadcast on } \\
\text { radio } \\
\text { First radio coverage } \\
\text { of the World Series } \\
\text { broadcast by WJZ } \\
\text { Van and Schenck, } \\
\text { 'Ain't We Got Fun?' } \\
\text { Irving Berlin, 'All by } \\
\text { Myself' and 'Say it } \\
\text { with Music' }\end{array}$ & $\begin{array}{l}\text { Ralph Steiner, } \\
\text { Typewriter Keys } \\
\text { Charles Demuth, } \\
\text { Incense of a New } \\
\text { Church and Business } \\
\text { Stuart Davis, Bull } \\
\text { Durbam and Lucky } \\
\text { Strike }\end{array}$ \\
\hline
\end{tabular}




\begin{tabular}{|c|c|c|c|}
\hline Date & Events & Criticism & Literature \\
\hline 1922 & $\begin{array}{l}\text { Wage cuts cause } \\
600,000 \text { coal miners } \\
\text { and } 400,000 \text { railroad } \\
\text { workers to strike. } \\
\text { Aimee Semple } \\
\text { McPherson becomes } \\
\text { first female radio } \\
\text { evangelist. } \\
\text { Tutankhamen's } \\
\text { Tomb discovered by } \\
\text { British archaeologist } \\
\text { Howard Carter. } \\
\text { Vitamins D and E } \\
\text { discovered. } \\
\text { Copies of James } \\
\text { Joyce's banned } \\
\text { Ulysses destroyed by } \\
\text { US Post Office. }\end{array}$ & $\begin{array}{l}\text { Secession (to 1924) } \\
\text { and The Fugitive (to } \\
\text { 1925) founded } \\
\text { Harold Stearns (ed.), } \\
\text { Civilization In the } \\
\text { United States } \\
\text { William Fielding } \\
\text { Ogburn, Social } \\
\text { Change with Respect } \\
\text { to Culture and } \\
\text { Original Nature } \\
\text { Walter Lippman, } \\
\text { Public Opinion } \\
\text { Margaret Sanger, The } \\
\text { Pivot of Civilization } \\
\text { John Dewey, 'The } \\
\text { American Intellectual } \\
\text { Frontier' } \\
\text { Reader's Digest } \\
\text { begins }\end{array}$ & $\begin{array}{l}\text { T. S. Eliot, The Waste } \\
\text { Land } \\
\text { James Weldon } \\
\text { Johnson, The Book } \\
\text { of American Negro } \\
\text { Poetry } \\
\text { Sinclair Lewis, } \\
\text { Babbitt } \\
\text { F. Scott Fitzgerald, } \\
\text { The Beautiful and the } \\
\text { Damned and Tales of } \\
\text { the Jazz Age } \\
\text { T. S. Stribling, } \\
\text { Birthright } \\
\text { Claude Mckay, 'The } \\
\text { White House' } \\
\text { Harry Leon Wilson, } \\
\text { Merton of the Movies }\end{array}$ \\
\hline 1923 & $\begin{array}{l}\text { President Harding } \\
\text { dies; Calvin Coolidge } \\
\text { assumes presidency. } \\
\text { Teapot Dome scandal } \\
\text { emerges. } \\
\text { First birth control } \\
\text { clinic opens in New } \\
\text { York. } \\
\text { Tax cut from } 50 \text { to } 40 \\
\text { per cent for the rich. } \\
\text { Émile Coué makes } \\
\text { his first tour of the } \\
\text { US. }\end{array}$ & $\begin{array}{l}\text { First issue of Time } \\
\text { published } \\
\text { Opportunity: A } \\
\text { Journal of Negro Life } \\
\text { first published } \\
\text { Marcus Garvey, } \\
\text { The Philosophy and } \\
\text { Opinions of Marcus } \\
\text { Garvey } \\
\text { D. H. Lawrence, } \\
\text { Studies in Classic } \\
\text { American Literature } \\
\text { Upton Sinclair, The } \\
\text { Goose-Step }\end{array}$ & $\begin{array}{l}\text { Jean Toomer, Cane } \\
\text { William Carlos } \\
\text { Williams, Spring and } \\
\text { All and The Great } \\
\text { American Novel } \\
\text { Wallace Stevens, } \\
\text { Harmonium } \\
\text { Waldo Frank, } \\
\text { Holiday } \\
\text { Langston Hughes, } \\
\text { 'The Weary Blues' } \\
\text { Gertrude Atherton, } \\
\text { Black Oxen }\end{array}$ \\
\hline
\end{tabular}




\begin{tabular}{|c|c|c|c|}
\hline Performance & Film & Music and Radio & Art and Design \\
\hline $\begin{array}{l}\text { Eugene O'Neill, The } \\
\text { Hairy Ape } \\
\text { George White's } \\
\text { musical revue } \\
\text { 'Scandals of 1922' }\end{array}$ & $\begin{array}{l}\text { Nanook of the North } \\
\text { (Robert Flaherty) } \\
\text { Will Hays becomes } \\
\text { Director of the } \\
\text { Motion Picture } \\
\text { Producers and } \\
\text { Distributors of } \\
\text { America (MPPDA) } \\
\text { Grauman's Egyptian } \\
\text { Theater opens in Los } \\
\text { Angeles }\end{array}$ & $\begin{array}{l}\text { Louis Armstrong } \\
\text { moves to Chicago } \\
\text { Duke Ellington } \\
\text { moves to New } \\
\text { York with 'The } \\
\text { Washingtonians' } \\
\text { George Anteil, Jazz } \\
\text { Sonata and Death of } \\
\text { the Machines } \\
\text { First pre-assembled } \\
\text { radios go on sale } \\
\text { Fiddlin' John } \\
\text { Carson first plays on } \\
\text { Atlanta's WSB }\end{array}$ & $\begin{array}{l}\text { Paul Strand's Double } \\
\text { Akeley } \\
\text { Charles Sheeler, } \\
\text { Skyscraper and } \\
\text { Offices } \\
\text { Gerald Murphy, } \\
\text { Engine Room } \\
\text { Ralph Steiner, } \\
\text { Always Camels } \\
\text { John Howells and } \\
\text { Raymond Hood win } \\
\text { the Chicago Tribune } \\
\text { Tower competition. }\end{array}$ \\
\hline
\end{tabular}

Elmer Rice's The

Adding Machine

Musical revue

'Runnin Wild'

introduces 'The

Charleston' to

mainstream America

Alma Cummings

wins the first

American dance

marathon
Harold Lloyd in

Safety Last

Flaming Youth (John

Francis Dillon)

The Covered Wagon

(James Cruz)

The Ten

Commandments

(Cecil B. DeMille)

First $16 \mathrm{~mm}$ camera

produced
Bessie Smith records George Bellows, 'Downhearted Blues' Between Rounds and 'Gulf Coast Charles Sheeler, Blues' Bucks County Barn

Billy Jones' 'Yes, We Paul Outerbridge, Have No Bananas' a Jello Mold in Dish hit song King Oliver's Creole Jazz Band, 'Chimes Blues'

Bix Beiderbecke Man Ray, Object to be Destroyed Louis Lozowick, Pittsburgh, Chicago and Cleveland forms the Wolverines

The A\&P Gypsies becomes the first band created by a radio sponsor 


\begin{tabular}{|c|c|c|c|}
\hline Date & Events & Criticism & Literature \\
\hline 1924 & $\begin{array}{l}\text { Richard Loeb and } \\
\text { Nathan Leopold } \\
\text { found guilty of } \\
\text { murdering Bobby } \\
\text { Franks. } \\
\text { National Origins Act } \\
\text { increases immigration } \\
\text { restrictions. } \\
\text { Buck v. Bell makes } \\
\text { forcible sterilisation } \\
\text { constitutional. } \\
\text { Ku Klux Klan } \\
\text { reaches height of } \\
\text { popularity with } 5 \\
\text { million supporters. } \\
\text { Senate votes to bar all } \\
\text { Japanese immigrants } \\
\text { to the US. } \\
\text { J. Edgar Hoover } \\
\text { becomes head } \\
\text { of the Bureau of } \\
\text { Investigation. } \\
\text { Hitler publishes } \\
\text { Mein Kampf. }\end{array}$ & $\begin{array}{l}\text { H. L. Mencken and } \\
\text { George Nathan } \\
\text { begin The American } \\
\text { Mercury } \\
\text { Saturday Review of } \\
\text { Literature founded } \\
\text { W. E. B. Du Bois, } \\
\text { The Gift of Black } \\
\text { Folk } \\
\text { Ford Madox } \\
\text { Ford founds The } \\
\text { Transatlantic Review } \\
\text { Gilbert Seldes, The } \\
\text { Seven Lively Arts } \\
\text { Lulu Hunt Peters' } \\
\text { Diet and Health } \\
\text { becomes non-fiction } \\
\text { bestseller }\end{array}$ & $\begin{array}{l}\text { Edna Ferber, So Big } \\
\text { John Crowe Ransom, } \\
\text { Chills and Fever } \\
\text { Marianne Moore, } \\
\text { Observations } \\
\text { Julia Peterkin, Green } \\
\text { Thursday } \\
\text { Walter White, The } \\
\text { Fire in the Flint }\end{array}$ \\
\hline 1925 & $\begin{array}{l}\text { John Scopes } \\
\text { convicted of teaching } \\
\text { the theory of } \\
\text { evolution. } \\
\text { KKK rally } 40,000 \text { in } \\
\text { Washington DC. } \\
\text { Electrical condenser } \\
\text { microphone } \\
\text { introduced. } \\
\text { Pickwick Club in } \\
\text { Boston collapses. }\end{array}$ & $\begin{array}{l}\text { Irving Babbitt, } \\
\text { Democracy and } \\
\text { Leadership } \\
\text { Bruce Barton, The } \\
\text { Man Nobody Knows } \\
\text { Frederic Thrasher, } \\
\text { The City } \\
\text { The New Yorker first } \\
\text { published } \\
\text { Alain Locke (ed.), } \\
\text { The New Negro } \\
\text { Marita Bonner, } \\
\text { 'On Being Young, } \\
\text { a Woman, and } \\
\text { Colored' }\end{array}$ & $\begin{array}{l}\text { F. Scott Fitzgerald, } \\
\text { The Great Gatsby } \\
\text { John Dos Passos, } \\
\text { Manhattan Transfer } \\
\text { Sherwood Anderson, } \\
\text { Dark Laughter } \\
\text { Willa Cather, The } \\
\text { Professor's House } \\
\text { Ernest Hemingway, } \\
\text { In Our Time } \\
\text { Gertrude Stein, The } \\
\text { Making of Americans } \\
\text { William Carlos } \\
\text { Williams, In the } \\
\text { American Grain } \\
\text { Theodore Dreiser, } \\
\text { An American } \\
\text { Tragedy } \\
\text { T. S Eliot, Poems } \\
\text { 1909-1925 } \\
\text { Ellen Glasgow, } \\
\text { Barren Ground }\end{array}$ \\
\hline
\end{tabular}




\begin{tabular}{|c|c|c|c|}
\hline Performance & Film & Music and Radio & Art and Design \\
\hline $\begin{array}{l}\text { Maxwell Anderson } \\
\text { and Laurence } \\
\text { Stallings, What Price } \\
\text { Glory? } \\
\text { Eugene O'Neill, } \\
\text { Desire Under the } \\
\text { Elms } \\
\text { Paul Whiteman's } \\
\text { first 'Experiment in } \\
\text { Modern Music' } \\
\text { Flagpole sitting fad } \\
\text { begins }\end{array}$ & $\begin{array}{l}\text { The Thief of Bagdad } \\
\text { (Raoul Walsh) } \\
\text { The Iron Horse (John } \\
\text { Ford) } \\
\text { Manhandled (Allan } \\
\text { Dwan) } \\
\text { Greed (Erich Von } \\
\text { Stroheim) }\end{array}$ & $\begin{array}{l}\text { Al Jolson, } \\
\text { 'California, Here I } \\
\text { Come' } \\
\text { Photographs } \\
\text { transmitted by } \\
\text { wireless between } \\
\text { London and New } \\
\text { York } \\
\text { National conventions } \\
\text { of the Republican } \\
\text { and Democratic } \\
\text { parties broadcast } \\
\text { nationally for the } \\
\text { first time }\end{array}$ & $\begin{array}{l}\text { George Bellows, } \\
\text { Dempsey and Firpo } \\
\text { Gerald Murphy, } \\
\text { Odol and Razor } \\
\text { Paul Rosenfeld, Port } \\
\text { of New York: Essays } \\
\text { American Radiator } \\
\text { Building completed } \\
\text { Georgia O'Keeffe, } \\
\text { Dark Abstraction } \\
\text { Debut of Little } \\
\text { Orphan Annie comic } \\
\text { strip }\end{array}$ \\
\hline
\end{tabular}

'The Coconuts' starring the Marx Brothers with songs by Irving Berlin John Alden Carpenter, Skyscrapers Paul Whiteman's 'Second Experiment in Modern Music'

The Gold Rush
(Charles Chaplin)
The Big Parade
(King Vidor)
The Phantom of
the Opera (Rupert
Julian)

Louis Armstrong and Bessie Smith record 'St Louis Blues' Bessie Smith records 'Lonesome Desert Blues'

George Anteil, Jazz Symphony Louis Gruenberg, Jazzberries and The Daniel Jazz Warner Brothers begin radio broadcasting from KFWB in Los Angeles

\section{Exposition}

Internationale des Arts Décoratifs et Industriels Modernes in Paris Georgia O'Keeffe and Alfred Stieglitz move to the Shelton Hotel Georgia O'Keeffe, New York with Moon Aaron Douglas, Invincible Music: The Spirit of Africa Man Ray, Clock Wheels Arthur Dove, Miss Woolworth 


\begin{tabular}{|c|c|c|c|}
\hline Date & Events & Criticism & Literature \\
\hline 1926 & $\begin{array}{l}\text { Tax cuts from } 40 \text { to } \\
20 \text { per cent for the } \\
\text { wealthy. } \\
\text { Great Miami } \\
\text { Hurricane causes } \\
\$ 100 \text { million damage } \\
\text { and ends land boom. } \\
\text { Gertrude Ederle } \\
\text { swims the English } \\
\text { Channel. } \\
\text { Rudolph Valentino } \\
\text { and Harry Houdini } \\
\text { die prematurely. } \\
\text { Vitamin B1 } \\
\text { discovered. }\end{array}$ & $\begin{array}{l}\text { Langston Hughes, } \\
\text { 'The Negro Artist } \\
\text { and the Racial } \\
\text { Mountain' } \\
\text { Langston Hughes, } \\
\text { Zora Neale Hurston, } \\
\text { Wallace Thurman, } \\
\text { Aaron Douglas, } \\
\text { Bruce Nugent, } \\
\text { Gwendolyn Bennett } \\
\text { and John P. Davis } \\
\text { publish Fire!! } \\
\text { H. L. Mencken, } \\
\text { Notes on Democracy } \\
\text { New Masses } \\
\text { magazine founded } \\
\text { Book-of-the-Month } \\
\text { Club founded }\end{array}$ & $\begin{array}{l}\text { Ernest Hemingway, } \\
\text { The Sun Also Rises } \\
\text { Langston Hughes, } \\
\text { The Weary Blues } \\
\text { Carl Van Vechten, } \\
\text { Nigger Heaven } \\
\text { William Faulkner, } \\
\text { Soldiers' Pay } \\
\text { Hart Crane, White } \\
\text { Buildings } \\
\text { Elizabeth Madox } \\
\text { Roberts, The Time } \\
\text { of Man } \\
\text { Frances Newman, } \\
\text { The Hard-Boiled } \\
\text { Virgin } \\
\text { Anita Loos, } \\
\text { Gentlemen Prefer } \\
\text { Blondes }\end{array}$ \\
\hline 1927 & $\begin{array}{l}\text { Charles Lindbergh } \\
\text { flies non-stop from } \\
\text { New York to Paris. } \\
\text { Sacco and Vanzetti } \\
\text { executed. } \\
\text { Henry Ford's } \\
\text { production line } \\
\text { opens at the River } \\
\text { Rouge factory. } \\
\text { First long-range } \\
\text { television signal } \\
\text { transmitted from } \\
\text { Washington DC to } \\
\text { New York. } \\
\text { Babe Ruth hits his } \\
\text { 60th home run of } \\
\text { the season (a record } \\
\text { unbroken until 1961). }\end{array}$ & $\begin{array}{l}\text { Charles Beard, The } \\
\text { Rise of American } \\
\text { Civilization } \\
\text { Vernon L. } \\
\text { Parrington, Main } \\
\text { Currents in American } \\
\text { Thought } \\
\text { Judge Ben B. } \\
\text { Lindsay and } \\
\text { Wainwright Evans, } \\
\text { The Companionate } \\
\text { Marriage } \\
\text { Joseph Wood } \\
\text { Krutch, 'The Modern } \\
\text { Temper' }\end{array}$ & $\begin{array}{l}\text { Sinclair Lewis, Elmer } \\
\text { Gantry } \\
\text { Langston Hughes, } \\
\text { Fine Clothes to the } \\
\text { Jew } \\
\text { Willa Cather, Death } \\
\text { Comes for the } \\
\text { Archbishop } \\
\text { Ernest Hemingway, } \\
\text { Men Without Women } \\
\text { James Weldon } \\
\text { Johnson, God's } \\
\text { Trombones: Seven } \\
\text { Negro Sermons in } \\
\text { Verse } \\
\text { Elizabeth Madox } \\
\text { Robert, My Heart } \\
\text { and Flesh } \\
\text { Thorton Wilder, The } \\
\text { Bridge of San Luis } \\
\text { Rey }\end{array}$ \\
\hline
\end{tabular}




\begin{tabular}{|c|c|c|c|}
\hline Performance & Film & Music and Radio & Art and Design \\
\hline $\begin{array}{l}\text { Eugene O'Neill, The } \\
\text { Great God Brown } \\
\text { The Savoy Ballroom } \\
\text { opens in Harlem } \\
\text { Mae West, Sex } \\
\text { Paul Green, In } \\
\text { Abraham's Bosom }\end{array}$ & $\begin{array}{l}\text { Don Juan (Alan } \\
\text { Crosland) } \\
\text { What Price Glory? } \\
\text { (Raoul Walsh) } \\
\text { The Son of the Sheik } \\
\text { (George Fitzmaurice) } \\
\text { The Black Pirate } \\
\text { (Albert Parker) } \\
\text { Ella Cinders (Alfred } \\
\text { Green) } \\
\text { Moana (Robert } \\
\text { Flaherty) }\end{array}$ & $\begin{array}{l}\text { Louis Armstrong } \\
\text { records 'Heebie } \\
\text { Jeebies' } \\
\text { William Grant Still, } \\
\text { Levee Land } \\
\text { National } \\
\text { Broadcasting } \\
\text { Company (NBC) } \\
\text { founded } \\
\text { Jelly Roll Morton, } \\
\text { 'Black Bottom } \\
\text { Stomp' } \\
\text { Vincent Lopez, } \\
\text { 'Always' }\end{array}$ & $\begin{array}{l}\text { Harmon Foundation } \\
\text { holds first annual art } \\
\text { exhibition of Negro } \\
\text { Art } \\
\text { Archibald John } \\
\text { Motley Jr, Cocktails } \\
\text { Chrysler Building } \\
\text { started } \\
\text { Georgia O'Keeffe, } \\
\text { City Night } \\
\text { Edward Hopper, } \\
\text { Sunday }\end{array}$ \\
\hline
\end{tabular}

e.e. cummings, $\mathrm{Him}$

Jerome Kern and

Oscar Hammerstein,

Show Boat

George Anteil, Ballet

Mécanique and Jazz

Symphony performed

in Carnegie Hall

James Price Johnson,

Yamekraw
The Jazz Singer

(Alan Crosland)

Sunrise (F. W.

Murnau)

Underworld (Josef

Von Sternberg)

IT (Clarence Badger)

Flesh and the Devil

(Clarence Brown)

Buster Keaton stars

in The General

(Clyde Bruckman)

The Roxy opens in

New York
Duke Ellington

begins at the Cotton

Club

Victoria Spivey, 'T.

B. Blues'

Irving Berlin, 'Blue

Skies'

Duke Ellington,

'Black and Tan

Fantasy'

NBC links fifty

stations across

twenty-four states

for an all-day live

transmission of the

Lindbergh medal

award listened to by

thirty million people

Radio Act regulates

the radio industry
Machine Art

exhibition in $\mathrm{New}$

York

Charles Sheeler

photographs Ford's

River Rouge factory

Georgia O’Keeffe,

The Radiator

Building - Night,

New York

Arthur Dove,

George Gershwin

- Rhapsody in Blue

part $I$ and $I I$

Edward Hopper,

Automat and The

Drug Store 


\begin{tabular}{|c|c|c|c|}
\hline Date & Events & Criticism & Literature \\
\hline 1928 & $\begin{array}{l}\text { Republican Herbert } \\
\text { Hoover defeats Al } \\
\text { Smith in a landslide } \\
\text { election for the } \\
\text { presidency. } \\
\text { Ruth Snyder's } \\
\text { execution pictured } \\
\text { on front page of the } \\
\text { New York Daily } \\
\text { News. } \\
\text { Alexander Fleming } \\
\text { discovers penicillin. } \\
\text { Vitamin C } \\
\text { discovered. } \\
\text { Great Okeechobee }\end{array}$ & $\begin{array}{l}\text { Margaret Mead, } \\
\text { Coming of Age in } \\
\text { Samoa } \\
\text { Zora Neale Hurston, } \\
\text { 'How It Feels to Be } \\
\text { Colored Me' } \\
\text { Franz Boas, } \\
\text { Anthropology and } \\
\text { Modern Life } \\
\text { American Literature } \\
\text { journal started }\end{array}$ & $\begin{array}{l}\text { Allen Tate, Mr Pope } \\
\text { and Other Poems } \\
\text { Claude McKay, } \\
\text { Home to Harlem } \\
\text { Djuna Barnes, The } \\
\text { Ladies Almanack } \\
\text { Nella Larsen, } \\
\text { Quicksand } \\
\text { Jessie Fauset, Plum } \\
\text { Bun: A Novel } \\
\text { Without a Moral } \\
\text { Upton Sinclair, } \\
\text { Boston } \\
\text { Vina Delmar, Bad } \\
\text { Girl }\end{array}$ \\
\hline
\end{tabular}

First coast-to-coast airline created.

The stock market crashes in late October; twentynine million shares sold in five days. Gastonia Strike. St Valentine's Day Massacre kills six gangsters and a bystander.

$\begin{array}{ll}\text { Walter White, } & \text { Ernest Hemingway, } \\ \text { Rope and Faggot: A } & \text { A Farewell to Arms } \\ \text { Biography of Judge } & \text { Wallace Thurman, } \\ \text { Lynch } & \text { The Blacker the } \\ \text { Robert and Helen } & \text { Berry } \\ \text { Lynd, Middletown } & \text { Thomas Wolfe, Look } \\ \text { John Dewey, The } & \text { Homeward Angel } \\ \text { Quest for Certainty } & \text { William Faulkner, } \\ \text { Joseph Wood } & \text { Sartoris and The } \\ \text { Krutch, The Modern } & \text { Sound and the Fury } \\ \text { Temper } & \text { Agnes Smedley, } \\ \text { James Truslow } & \text { Danghter of Earth } \\ \text { Adams, Our Business } & \text { Nella Larsen, Passing } \\ \text { Civilization: Some } & \text { Dashiell Hammet, } \\ \text { Aspects of American } & \text { Red Harvest } \\ \text { Culture } & \end{array}$




\begin{tabular}{|c|c|c|c|}
\hline Performance & Film & Music and Radio & Art and Design \\
\hline $\begin{array}{l}\text { Sophie Treadwell, } \\
\text { Machinal } \\
\text { Eugene O’Neill, } \\
\text { Strange Interlude } \\
\text { Martha Graham } \\
\text { performs Immigrant: } \\
\text { Steerage, Strike } \\
\text { George Gershwin's } \\
\text { An American in Paris } \\
\text { premiers at Carnegie } \\
\text { Hall } \\
\text { The Marx Brothers } \\
\text { star in Animal } \\
\text { Crackers }\end{array}$ & $\begin{array}{l}\text { The Crowd (King } \\
\text { Vidor) } \\
\text { Our Dancing } \\
\text { Danghters (Harry } \\
\text { Beaumont) } \\
\text { The Wedding March } \\
\text { (Erich Von Stroheim) } \\
\text { Speedy (Harold } \\
\text { Lloyd) } \\
\text { Walt Disney } \\
\text { produces first } \\
\text { Mickey Mouse } \\
\text { cartoon, Plane } \\
\text { Crazy, followed } \\
\text { by his first sound } \\
\text { animation Steamboat } \\
\text { Willie }\end{array}$ & $\begin{array}{l}\text { Louis Armstrong, } \\
\text { 'West End Blues' } \\
\text { Ruth Etting, 'Love } \\
\text { Me or Leave Me' } \\
\text { Helen Kane, 'I } \\
\text { Wanna Be Loved By } \\
\text { You' } \\
\text { Will Rogers Program } \\
\text { broadcast to millions } \\
\text { on NBC } \\
\text { First car radios } \\
\text { manufactured }\end{array}$ & $\begin{array}{l}\text { Demuth, I Saw the } \\
\text { Figure } 5 \\
\text { Margaret Bourke- } \\
\text { White, Niagara Falls } \\
\text { Generators } \\
\text { Edward Hopper, } \\
\text { Manhattan Bridge } \\
\text { Loop and Night } \\
\text { Windows } \\
\text { Charles Sheeler, } \\
\text { River Rouge } \\
\text { Industrial Plant } \\
\text { Buckminster Fuller } \\
\text { introduces his } \\
\text { Dymaxion House }\end{array}$ \\
\hline $\begin{array}{l}\text { Elmer Rice, The } \\
\text { Subway: A Play in } \\
\text { Nine Scenes } \\
\text { Eugene O'Neill, } \\
\text { Dynamo }\end{array}$ & $\begin{array}{l}\text { Black and Tan } \\
\text { starring Duke } \\
\text { Ellington } \\
\text { St. Louis Blues } \\
\text { starring Bessie Smith } \\
\text { Hallelujah (King } \\
\text { Vidor) } \\
\text { The Broadway } \\
\text { Melody (Harry } \\
\text { Beaumont) }\end{array}$ & $\begin{array}{l}\text { Fats Waller and } \\
\text { Louis Armstrong, } \\
\text { 'Aint Misbehavin' } \\
\text { The Rounders and } \\
\text { The Brox Sisters, } \\
\text { 'Singing in the Rain' } \\
\text { Bessie Smith, 'Wasted } \\
\text { Life Blues' } \\
\text { Amos 'n' Andy radio } \\
\text { show first broadcast } \\
\text { on NBC }\end{array}$ & $\begin{array}{l}\text { Alexander Calder, } \\
\text { Circus } \\
\text { Charles Sheeler, } \\
\text { Upper Deck } \\
\text { Thomas Hart } \\
\text { Benton, Georgia } \\
\text { Cotton Pickers } \\
\text { Museum of Modern } \\
\text { Art founded } \\
\text { Hugh Ferris } \\
\text { publishes the } \\
\text { Metropolis of } \\
\text { Tomorrow }\end{array}$ \\
\hline
\end{tabular}


